\title{
14
}

\section{Social Movements and Failed Institutionalization: Corporate (Non)Response to the AIDS Epidemic}

\author{
Gerald F. Davis and Peter J.J. Anderson
}

A consequence of globalization is that the nation-state becomes too big to solve the small problems and too small to solve the big ones, as Daniel Bell has remarked. The same might be said of the contemporary multinational corporation (MNCs). As MNCs have grown in size and influence in recent decades, they have faced growing demands to assume greater responsibility for solving social problems large and small. Corporations are expected to provide safe products for their consumers, decent working conditions for their employees, and to police the ethical standards of their suppliers and even the countries where they operate. More recently, MNCs have been asked to address global problems that would have previously been seen as the responsibility of governments, such as the HIV/AIDS pandemic and the looming crisis of climate change. Such problems outstrip the capacities of individual states to respond effectively. They require a collective response, from governments and from transnational actors such as corporations. Yet demands to address broad social problems challenge conceptions of what a corporation is for, and to whom it owes a responsibility. How are we to understand corporate responses to demands for greater responsibility in addressing global problems?

In this chapter, we argue that organizational institutionalism and social movement theory offer complementary insights to address what we might call 'collective corporate social responsibility.' Collective corporate social responsibility (CCSR) is the concept that organizations in a sector or field are perceived to owe an obligation to certain constituencies. These obligations can vary across fields and over time. For example, businesses headquartered in Minneapolis are expected to 
provide generous support to local non-profits, while businesses in Phoenix face no such expectation (Marquis, Glynn and Davis, 2007). Pharmaceutical companies are expected to provide access to their products for those who cannot afford them, while packaged food companies are not. And thanks to the antisweatshop movement, brand-name sneaker companies are now expected to vouch for the labor practices of offshore suppliers who were previously regarded as outside the realm of their responsibility (Davis Whitman and Zald, 2007). CCSR attaches to organizations by virtue of their membership in a field. Efforts to expand the definition of what organizations in a particular field are responsible for - by social movements and others - can thus be regarded as institutionalization projects: they attempt to change the definition of what field members are and where their responsibilities lie. As institutionalists point out, organizations adopt practices and structures in large part because these are regarded as appropriate and legitimate within their organizational field (DiMaggio and Powell, 1983). Thus, attempts to induce corporations to take on expanded responsibilities, by social movements and others, entail expanding field-level definitions of the appropriate.

We focus on a particular episode that we regard as a failed institutionalization project: the effort to engage American multinationals in the collective global battle against the HIV/AIDS pandemic. This is a particularly illuminating case for several reasons. The AIDS pandemic is the largest public health crisis in contemporary history, and the consequences of inaction range from the highly personal to problems of national security and economic development. Unlike emergent crises such as climate change, the scope of the problem is manifest, and the death toll already numbers in the millions, particularly in sub-Saharan Africa. Many of the nations facing the gravest problems are among the poorest in the world, some nominally governed by 'failed states.' If ever there were a problem requiring coordinated outside help from the corporate sector, this was it.
American businesses were offered a relatively low-cost vehicle sanctioned by the United Nations to participate in the fight against AIDS. In January 2001, Secretary General Kofi Annan urged American businesses to join the Global Business Coalition on HIV/AIDS (GBC), headed by former American UN ambassador and investment banker Richard Holbrooke. Annan framed his appeal to align with prevalent American conceptions of the corporation, highlighting the benefits to shareholders and other constituencies. Yet roughly $95 \%$ of the largest American businesses declined, and those that did join were a somewhat idiosyncratic group. Why did some join, and most decline?

Our findings suggest that institutionalization projects are analogous to efforts to build a social movement (cf. Schneiberg and Lounsbury, this volume). Successful institutional entrepreneurs induce a critical mass to adopt their definitions of appropriatenesswhat kind of engine should an automobile have (Rao, 2002), what activities should an accounting firm do (Greenwood and Suddaby, 2006), what are a company's obligations to the local non-profit community (Marquis et al., 2007), or to gay and lesbian employees (Scully and Creed, 2005), or to citizens in need in other countries. Fomenting a social movement follows a similar dynamic, as institutional entrepreneurs (such as Kofi Annan) seek to change a critical mass of actors' conception of their obligations - in this case, what a multinational company can and should do about HIV/AIDS. Some actors are prone to joining a movement based on interests pharmaceutical companies, for instance, have a clear stake in efforts to address HIV/AIDS, and firms with substantial foreign sales receive a benefit in learning from their peers. Others have already adopted a conception of their obligations consistent with the movement, making them easier to recruit; in this case, those companies that had benefits packages for domestic partners of gay and lesbian employees were far more likely to join than those that did not. But to 
achieve a critical mass, institutional and movement entrepreneurs often need effective recruitment networks. And while there was clear evidence of network-based recruitment in this instance, it was not sufficient to spread beyond the 'early adopters.' Within five years of Annan's plea, only about two dozen members of the Fortune 500 had joined the GBC. That is, joining the global fight against HIV/AIDS had not become institutionalized as part of the standard package of what MNCs do.

We next provide some background on the parallels between organizational institutionalism and social movement theory, and recent efforts to integrate them. We then describe the context of the corporate movement against HIV/AIDS, and derive some hypotheses about which companies are prone to joining. We analyze data on a sample of the several hundred largest US firms for this decade, and conclude with some implications of our findings for organizational institutionalism.

\section{THEORETICAL BACKGROUND}

In recent years there has been a notable convergence in the agendas of those that study organizations - particularly institutional theorists - and those that study social movements. There are several reasons for this convergence (Davis and Zald, 2005). First, since both domains are concerned with the sources of organized action, they are characterized by similar processes and mechanisms: founding, structuring, recruiting, incentives, leadership, and culture are all central concerns of both. While social movements often come to be represented by formal organizations, organizations have come to be less formal, more permeable, transient, and network-like (Davis and McAdam, 2000). Second, both movements and organizations have been transformed by globalization and the advent of information and communication technologies (ICTs), including mobile phones, computers, and the World Wide Web. The globalization of trade and finance has been accompanied by the growth of transnational movements and corporations that are dispersed across national boundaries. And thanks to ICTs, both movements and organizations are often characterized by nimble and relatively ad hoc alliances assembled for particular performances. Multinational quasi-firms can be assembled for specific projects - a movie, a skyscraper, a line of mobile phones - and broken up when the project concludes. Similarly, protest actions, such as those against the WTO, typically comprise temporary alliances among separate sponsors. Social movements have become as global as corporations: six million protesters marched on the same day in February 2003 behind the banner 'The World Says No to War' at dozens of cities on six continents in anticipation of the American invasion of Iraq, with streaming video feeds of the action available around the world via the Web. Finally, organizations are often both the objects of social movements - e.g., Nike (for its contractors' labor practices), Nestlé (for its sales of infant formula in impoverished countries lacking clean water), Shell (for its operations in repressive states); the sites of social movements (such as efforts to gain equal employment rights), and participants in social movements (Davis, McAdam, Scott, and Zald, 2005). Corporations participate in social movements both covertly (e.g., as funders for 'social movement organizations' intended to advocate for the firm's agenda) and overtly (e.g., through alliances, board affiliations, and sponsorships).

The imagery of networks and contagion are common to research on both institutions and social movements (Strang and Soule, 1998). Networks provide a bridge between individual and collective action: actors adopt innovations in part because those they are connected to have done so, and potential activists 'adopt' movement membership largely via network ties. The nature of relevant ties is quite variable. Networks created 
by shared directors provide an infrastructure for the spread of governance practices among corporations (e.g., Davis and Greve, 1997), organizational structures such as the multidivisional form (e.g., Palmer, Jennings, and Zhou, 1993), and even choices about which stock market to list on (Rao, Davis, and Ward, 2000). Organizations are also linked by professional networks, such as those created by human resource managers and their professional associations (Dobbin, Sutton, Meyer, and Scott, 1993). At a more informal level, organizations can be connected by networks of social activists; for instance, gay/lesbian/bisexual/transgender (GLBT) employee groups shared best practices and tactics among their peers to advocate for domestic partner health benefits at employers across America (Scully and Creed, 2005). Geographic proximity can create connections among organizations that are consequential for corporate practice (e.g., Marquis, 2003). And organizations can also be connected through more abstract ties, such as social proximity (e.g., operating in the same industry). Any of these connections can provide a substrate for contagion, or cohesion for the purposes of collective action.

Institutional theorists have drawn on contagion imagery to unpack episodes of widespread organizational change. The prevalence of a practice or structure is typically taken as evidence for its legitimacy, and thus a prod to further adoption. For example, Tolbert and Zucker examined the spread of municipal reform among American cities, finding that later adopters evidently drew on the prevalence of the reform as a sign of its appropriateness. Fligstein (1990) described how field-level changes in the rules of the game - antitrust regulations limiting certain types of horizontal and vertical mergers prompted firms to experiment with alternative strategies to achieve growth and stability, enacted by CEOs with particular types of functional background and training. Those strategies that proved successful then spread widely through mimicry, first within their industry and later more broadly, leaving behind a cadre of top executives with a particular kind of orientation. Edelman (1992) described a similar dynamic in the context of employment relations: in the wake of the Civil Rights Acts of the 1960s, employers experimented with alternative structures to signify compliance with government requirements for equal employment opportunity. Those that proved sufficient to ward off legal challenge subsequently spread widely through mimicry. Again, a concomitant of the spread of equal employment offices was the spread of equal employment officers professionals with a particular background and training, sensitized to particular issues.

An implication of this discussion is that networks are both a cause and a consequence of contagion. Actors draw on existing networks (through shared directors, common membership in professional or industry associations, geographic proximity, and so on) to make judgments about the appropriateness of innovations, such as poison pills or GLBT partner benefits. But episodes of contagion can also end up creating networks of firms that regard each other as models or peers. American antitrust law created opportunities for CEOs from a finance background; these CEOs, in turn, promoted corporate strategies of diversification. They acted, in effect, as agents of a particular worldview, implanted within organizations and oriented to the actions of their peers. Similarly, employment laws created opportunities for human resource managers. Once in place, these managers became oriented toward peer groups ('benchmarks'), and act as advocates for new innovations in human resource management, such as maternity leave (Kelly and Dobbin, 1999). It is as if by hiring these professionals, the organization had grown a new sense organ that attuned it to particular types of practice and structure.

Social movements can have a parallel effect on corporate change. Zald, Morrill, and Rao (2005) describe the various processes by which social movements can penetrate organizations. At the simplest level, employees bring with them their social 
identities and priorities. Feminist executives may be advocates for women-friendly corporate policies. Minority executives may shape hiring and promotion policies in ways consistent with an agenda of equality. Scully and Creed (2005) document how networks of gay and lesbian activists formed within and across companies to advocate for gay-friendly corporate policies. Informal networks allowed activists in different companies to compare notes on which tactics worked and which did not. Moreover, the groups could use each other's experiences to document the prevalence of particular practices and thus advocate for them more effectively. One of the most visible of these was the relatively widespread adoption of domestic partner benefits among large US corporations (Briscoe and Safford, 2005). Notably, these networks among employee groups were not neutral conduits for the spread of information or norms among organizations they were channels for activism. And the prevalence of a practice (such as domestic partner benefits) was not simply a benchmark, but a tool for advocacy. Activists could influence how information about best practices was brought into the organization and used to guide the organization's own policies (Briscoe and Safford, 2005).

Thus, both institutional theory and social movement theory draw on common images and mechanisms for organizational change (Davis et al., 2005). In this case, organizations are connected at multiple levels by networks among directors that serve on each others' boards, executives bound by common training, professionals connected through professional associations, and activists organized via social movements that cross organizational boundaries. Any of these can potentially provide a channel for recruitment to a social movement. But the process is not simply one of the dissemination of neutral information: recruitment requires active engagement and advocacy.

We examine the implications of this discussion of networks and change in the context of a failed institutionalization project: the effort to recruit corporations to a collective fight against HIV/AIDS. The several hundred largest US corporations can be considered an organizational field, a group of mutually-regarding actors that look to each other for evidence of appropriate action (Fligstein, 1990). They are connected more or less densely at multiple levels by director networks, professional networks, and activist networks, among others. The extent that this well-connected group adopts or fails to adopt a practice is an apt indicator of its institutionalization. In this case, the practice in question is membership in a UN-sanctioned business organization aimed at halting the spread of HIV/AIDS. Prevalence of adoption of this innovation stalled at about 5 percent, which we take as a sign of failed institutionalization. We first describe the context of the AIDS epidemic and then consider the factors that militate for or against joining the fight.

\section{CONTEXT: CALL AND (NON)RESPONSE}

In remarks made on the eve of World AIDS Day in 2004, UNAIDS Executive Director Peter Piot characterized his news about HIV/AIDS as both 'sobering' and 'ominous'. $\mathrm{He}$ explained that the number of people living with HIV globally had grown to nearly 40 million and that in 2004 alone, approximately 5 million people became infected with HIV and 3 million people died from AIDS-related causes. He indicated that the virus is perilously close to becoming a 'raging epidemic' in China, India and Russia and that its spread in these places bears alarming similarities to the situation in Africa two decades ago, where it took five years for HIV prevalence rates to move from 0.5 percent to 1 percent but only seven more years for such rates to jump from 1 percent to 20 percent. A 2004 report issued by the World Economic Forum (WEF) echoed Piot's warning while adding warnings about the economic consequences of the epidemic: 'The AIDS epidemic is first and foremost a 
human tragedy, but its magnitude also derives profound social and structural changes, leading to predictions of equally profound economic damage ... If effective action is not taken to combat the spread of this epidemic, HIV/AIDS could result in [total] economic collapse' (World Economic Forum, 2004: 3). Eberstadt (2002) suggested the following projections: a mild HIV epidemic would more than halve Russia and China's per person output growth between 2000 and 2025, while an intermediate epidemic would mean the predicted level of output in Russia would be lower in 2025 than 2000, and in China barely higher. In India, a mild epidemic would reduce output growth by about two-fifths and an intermediate outbreak would reduce growth to zero.

Despite the alarming costs that have already been incurred in sub-Saharan Africa and those that could likely occur in three of the world's largest countries, the American corporate sector's reaction has been modest, to put it mildly. A 2004 WEF Executive Opinion Survey found that 50 percent of American business executives believe that HIV/AIDS will have some impact on their business, yet only 7 percent of the executives surveyed indicated that their company has a written HIV/AIDS-specific policy and a mere 6 percent expressed confidence that their company's current response to HIV/AIDS was sufficient (Taylor, DeYoung and Boldrini, 2004). Executives acknowledge that HIV/AIDS is a significant global problem while simultaneously judging it not so pressing as to require immediate steps. Analysts at the WEF's Global Health Initiative suggest that this inactivity of the American corporate sector reflects the fact that firms lack appropriate information or incentives, and that they are unable to assess the risks they face as well as the potential costs and benefits from successful action (World Economic Forum, 2004).

In an effort to prod American business executives into action, UN Secretary-General Kofi Annan appeared before the US Chamber of Commerce in January 2001 and implored
America's business leaders to use their financial strength and influence to take increased and decisive global action to address HIV/AIDS:

I come to you, the leaders of American business, representatives of one of the greatest forces in the world, but one which has yet to be fully utilized in the campaign against AIDS/HIV. It is high time we tapped your strengths to the full ... Business is used to acting decisively and quickly. The same cannot be said of the community of sovereign states. We need your help - right now ... Together, I believe we can succeed - if only because the costs of failure are simply too appalling to contemplate. (Annan, 2001)

Annan asserted that multinational corporations are indispensable in the global fight against HIV/AIDS. They have the resources and skills that many failed states lack. As such, Annan's remarks were designed to remind the leaders of the American corporate sector that if they can flex their financial might around the world, they need to be prepared to similarly take decisive action in times of crises. He framed his call to action in business-friendly terms, emphasizing the benefits to reputation, customer loyalty, and shareholder value. Moreover, he endorsed the Global Business Coalition on HIV/AIDS (GBC) as the preferred vehicle for collective action. Joining the GBC took only $\$ 25,000$ ('Less than a benefit table at the opera,' as GBC's CEO Richard Holbrooke quipped), and it provided tangible benefits and a visible way to signal commitment to the fight against HIV/AIDS.

A number of international business coalitions have been formed for the purpose of creating a forum for collective action on HIV/AIDS. The first was created in Thailand in 1993. The Thailand Business Council on AIDS (TBCA) was founded by two expatriate businessmen who noted that many companies in and around Bangkok were quite concerned about HIV/AIDS but that none knew where to go for assistance in the development and implementation of an HIV/AIDS policy. The founders put up their own seed money to start the TBCA with a mission of channeling the creativity 
and dynamism of business executives to formulate solutions to resource, technical and strategic planning problems in mounting effective HIV/AIDS prevention and living with AIDS programs (Thailand Business Council on AIDS, 2000). The TBCA was established as a membership organization where each member firm pays a membership fee commensurate with the size of that firm and their level of commitment to TBCA and AIDS prevention in general. Within two years, the TBCA membership had grown to 85 companies, among them many large multinational firms such as 3M, American International Group, Bristol Myers Squibb, Colgate Palmolive, General Motors, Kodak and Shell. Membership now stands at approximately 120 firms.

Following the successful model of the TBCA, the Global Business Council on HIV \& AIDS (GBC) was established in 1997 as a small peer-to-peer international advocacy group with the purpose of promoting an enlarged and enhanced business response to HIV/AIDS. The four founding members Glaxo Wellcome (UK), Industrias Villares (Brazil), MTV International (US) and Tata Power (India) - formed the Council based on a shared belief that the corporate sector was not doing a fraction of what it could do to address HIV/AIDS despite the fact that it is a critical issue for every company precisely because it has no boundaries: it penetrates borders and threatens the world's emerging economies (Global Business Coalition on HIV/AIDS, 2004). Levi-Strauss, Bristol Myers Squibb and Merck had all joined the Council by 2000 , but for the first four years of its existence, the number of members remained low and the Council remained more of a peer group than a full-fledged organization. The importance of the Council changed significantly during a 2001 United Nations Session on HIV/AIDS. During the session, the UN Security Council called on the private sector to increase its engagement of the epidemic. As part of that mandate, the Security Council asked Richard Holbrooke, former US Ambassador to the United Nations, to take over as the President and CEO of the GBC and turn it into the primary vehicle for mobilizing the global business community. At that time, the Global Business Council was renamed the Global Business Coalition on HIV/AIDS to reflect the new effort to become a more inclusive organization with a more extensive corporate membership base. Under the leadership of Holbrooke, the GBC's membership grew from 17 in 2002 to more than 170 companies in 2005.

The GBC describes itself as the preeminent organization leading the business fight against HIV/AIDS and defines its role as working with global leaders in government, business and civil society, to promote greater partnerships in the global response to HIV/AIDS and identify new, innovative opportunities for the business sector to join the growing global movement against HIV/AIDS (Global Business Coalition on HIV/AIDS, 2004). The Coalition charges the same annual membership fee of $\$ 25,000$ to each member and the only expectation is that members will participate in ways that best suit them. The primary involvement of most member companies is through industryrelated or issue-related project working groups (e.g., the Biotechnology Working Group and the AIDS Orphans and Vulnerable Children Working Group); provision of advice on relevant international issues of importance to business; and sharing of best practices, particularly regarding companywide HIV/AIDS policies. In addition, those member companies specifically interested in developing an internal corporate HIV/AIDS policy utilize the GBC's exclusive Business AIDS Methodology ${ }^{\mathrm{TM}}$ (BAM). BAM is a business-management model created for the design and implementation of a customized company response to HIV/AIDS. Through an intensive process with GBC experts, BAM results in a strategic, goal-oriented action plan, tailormade to an individual company's characteristics and core competencies. The variety of activities and services 
notwithstanding, it is important to note that some GBC members are involved only to the extent that they pay the annual membership fee, thereby adding their company's reputation to the Coalition's work (Global Business Coalition on HIV/AIDS, 2004).

\section{HYPOTHESES}

We analyze the factors distinguishing those American firms that joined the Global Business Coalition on HIV/AIDS from those that did not to understand the institutional process behind corporate (non)response to the pandemic. We are particularly interested in understanding the social mechanisms - the 'cogs and wheels' that underlie corporate responses to the AIDS epidemic (Hedstrom and Swedberg, 1998). In doing so, we draw on institutional and social movement theories broadly for a suite of possible mechanisms.

Organizational institutionalism and social movement theory provide complementary ways of analyzing why firms would join the GBC. For social movement researchers, movements and social movement organizations such as the GBC are seen as special cases of collective action. Any form of collective action faces free rider problems - the benefits of successful collective action are shared widely, while the costs are borne by the individuals that join in the effort. These tendencies toward inaction are even more pronounced among organizations than among individuals: organizations are shortterm focused, prone to inertia, and respond to problems that have already occurred rather than to 'predictable surprises' that may happen in the future (Cyert and March, 1963; Bazerman and Watkins, 2004). The prognosis for corporate executives taking action on problems whose consequences will be felt on someone else's watch - such as the AIDS pandemic- is grim. Thus, movement researchers focus on a combination of individual and selective incentives for joining (or avoiding) movements and on social infrastructure, such as networks among potential joiners.

Institutionalists, as we have seen, view joining a movement as akin to the diffusion of an innovation. Like social movement researchers, they see networks as a potential substrate for contagion, as organizations facing uncertainty follow the example set by their alters (DiMaggio and Powell, 1991). Institutionalists also point to a central place for identity- that answering the question: 'What should I do in this situation?' often follows from determining 'Who am I, and what does someone like me do?' (DiMaggio and Powell, 1991). In the hypotheses that follow, we draw on each of these factors - incentives, networks, and identity -to draw out implications of social movements and institutionalism for which firms are likely to join the GBC.

Organizations that are larger and have better performance face greater incentives to join the fight against HIV/AIDS. First, large organizations are more visible to the public and therefore more likely to be the target of demands or appeals (like that of Kofi Annan before the US Chamber of Commerce) that emphasize their responsibility to take action. Prior research suggests that large organizations are more likely to be the target of social movement efforts than small organizations (Davis et al., 2005). Moreover, large firms find it rela-tively less costly to allocate resources to GBC membership fees and to develop and implement of HIV/AIDS policies. Second, theory on social movements suggest that slack resources enable more prospective collective action - in short, the rich can take the offense, while the poor must typically respond defensively (Tilly, 1978: ch. 3). In this context, superior organizational performance can create potential slack resources for experimentation and innovation that are unavailable to those with poor performance. Thus:

Hypothesis 1: The larger a firm and the better its performance, the more likely it is to join the $G B C$.

Firms with more global operations also have greater incentives to engage against 
the HIV/AIDS epidemic. Domestic firms face rather limited exposure to the epidemic, as the prevalence of HIV in the US is relatively low by world standards. Companies are expected to have increased exposure to HIV/AIDS to the extent that they sell their products and services on a global scale. As such, firms that have high levels of foreign sales are predicted to possess a more acute understanding of the damage the disease has wrought on both their employee and customer bases, and thus greater incentives to join in efforts to address it. To that end, levels of foreign sales should serve as a predictor for whether firms join the GBC.

Hypothesis 2: The greater a firm's sales outside the US., the more likely it is to join the $G B C$.

Certain key industries, such as the pharmaceutical industry, have critical business interests that draw them into the global effort to address HIV/AIDS. American pharmaceutical companies are among the leading producers of drugs that reduce the amount of virus in a HIV-positive patient's blood and help to delay the progress of disease. Yet American pharmaceutical companies have come under fire for what AIDS activists and AIDS sufferers (particularly the millions of African AIDS victims living in dire poverty) decry as impossibly expensive drugs. The drug companies contend that it is simply not feasible for them to reduce drug prices because doing so would severely undermine the research and development efforts being undertaken to produce new and potentially more effective drugs. Despite international patent laws that prohibit such action, African countries have sought less expensive generic drugs manufactured primarily in India. As a result of the continued battle that pharmaceutical firms have found themselves in, it is expected that they would make every effort to have a seat at the table of a powerful advocacy group such as the GBC. It is conceivable to imagine that without the presence of pharmaceutical firms, the GBC might support policies such as the global regulation of drug prices. Therefore, membership in the
GBC appears congruent with resource dependence theory's prediction that firms will take action to safeguard their key exchange relationships (Pfeffer \& Salancik, 1978). In addition, institutionalists point to the importance of responding to external evaluators, such as activists and governments in stricken countries, with symbolic displays of good faith (Meyer and Rowan, 1977). Although such displays may be de-coupled from the organization's actual operations, they serve an important institutional function in establishing the firms' social fitness - and potentially warding off more intrusive interventions.

Hypothesis 3: Pharmaceutical firms will be more likely to join the GBC than firms in other industries.

Not all such organizational changes are purely symbolic, of course. Organizations may establish offices or policies as displays of good faith, yet they may subsequently find that the symbol becomes a reality. A firm's internal policies can create employee constituencies that make the firm more attentive and responsive to certain social circumstances. The research by Sutton et al. (1994) and Sutton and Dobbin (1996) shows that the establishment of personnel, benefits and Equal Employment Opportunity offices created constituencies within firms that actively promoted practices advocated by their professional networks. A specific example is offered by Kelly and Dobbin (1999), who found that firms with benefits offices were more likely subsequently to create formal maternity leave policies. That is, the establishment of human resource offices - whatever the initial intention - connected firms into professional networks that conditioned their responses to subsequent innovations.

In a similar vein, HR policies related to domestic partner benefits may both result from and strengthen supportive constituencies for taking corporate action against HIV/AIDS within the organization. Briscoe and Safford (2005) document that domestic partner benefits were a major target of 
activism by GLBT employee groups in corporate America during the second half of the 1990s and the first half of the 2000s. Thus, 93 percent of firms with formal GLBT employee groups adopted domestic partner benefits during this time, compared to 41 percent of firms without such groups. We anticipate that firms in the vanguard of HR policies recognizing same-sex partnerships are likely to attract employees who are more attentive to the global HIV/AIDS epidemic and more likely to press for a proactive corporate response.

Hypothesis 4: Firms with more progressive $H R$ policies for gay employees will be more likely to join the $G B C$.

Viewing a firm's GBC membership as akin to the adoption of a particular corporate practice suggests an analogy with other forms of institutional diffusion. Davis and Greve (1997), for instance, found that when a company's directors served on the boards of other firms that had already adopted a poison pill, these directors were able to evaluate and even promote adoption. Thus, as more of one's contacts adopt, adoption may come to be seen as normatively appropriate. Such contagion processes are also characteristic of social activism: McAdam (1986) found that college students were more likely to participate in high-risk activism- specifically, joining the 1964 Freedom Summer project when they had friends that were also participating. McAdam found that a strong ideological identification with the civil rights movement could encourage action, but that the major factor distinguishing those that joined Freedom Summer and those that sat it out was having a friend that had joined. Similarly, we expect that firms which share a director with an existing member of the GBC will be more prone to this particular form of corporate activism: directors can spread the 'innovation' of GBC membership from board to board.

Hypothesis 5: Firms will be more likely to join the $G B C$ to the extent that they share directors with other firms that are members of the $G B C$.

\section{DATA AND METHOD}

We chose as our sampling frame the 2003 Fortune 500, that is, the largest 500 firms in the US by revenues. We excluded commercial banks and firms that were not publicly traded because certain measures (revenues, market capitalization, board membership) are either not comparable or not available for these firms. Our final sample consisted of 413 firms.

Our dependent variable was membership in the Global Business Coalition by 2004. Although there are a number of ways one might operationalize corporate responses to AIDS, membership in the GBC has several advantages as an indicator: it is unambiguous, non-trivial, and has the sanction of the United Nations. As of mid-2004, the GBC had 150 members, of which 76 were USbased firms and 23 were included in the Fortune 500.

Our independent measures came from several sources. Our measure of size (number of employees) and performance (the market-tobook ratio, that is, [market capitalization at fiscal year end]/[book value of shareholders' equity]) came from Compact Disclosure. Foreign sales, calculated as the ratio of nonUS sales to total sales for 2002 (or for the most recent available year), came from the geographic segment file of Compustat. Firms were classified as pharmaceutical companies if their primary three-digit SIC code was 283. For progressive HR policies, we drew on the Human Rights Campaign's WorkNet database (2004). Specifically, we used an indicator variable equaling one if the firm made domestic partner benefits available to gay and lesbian employees and zero otherwise, according to HRC's WorkNet. (Domestic partner benefits are health insurance and other benefits equivalent to those available to married heterosexual employees.)

We constructed our board interlock measure using board data for all firms traded on Nasdaq and the New York Stock Exchange in 2000. This sample included 47,349 directors serving on the boards of 
5,627 corporate boards. Board membership data were carefully cleaned to identify overlaps in which the same individual served on two or more boards. All firms in this expanded group were coded for membership in the GBC. Because several hundred nonUS firms are traded on these two markets, we included their data when calculating ties to GBC members. Our measure is a count of the number of other $\mathrm{NYSE}_{\mathrm{A}}$ or Nasdaq-traded firms with which a focal firm shared a director that were members of the GBC. Note that while only 23 Fortune 500 firms were members of the GBC, more than one-third of our Fortune 500 sample shared at least one director with a GBC member (either US or foreign).

We analyzed the data using logistic regression, with the dependent variable being membership in the GBC, as of 2004. Ideally, we would include a time-series model of membership, but because it is still a relatively rare event, we would lack sufficient statistical power to draw any inferences.

\section{RESULTS}

Descriptive statistics are reported in Table 14.1. The means show that membership in the GBC is somewhat rare, in spite of the fact that the GBC is perhaps the world's most influential business coalition addressing the AIDS epidemic. Yet board-level ties to GBC members are relatively widespread: more than one-third of the firms in our sample share a director with a GBC member, and some firms share directors with up to seven other members (e.g., Xerox). We also see that domestic partner benefits are more prevalent among large firms than one might have anticipated. Correlations among the independent variables are generally modest, with the notable exception of the correlation between domestic partner benefits and ties to GBC members, which is correlated at 0.25 .

Table 14.2 shows the results of the logistic regression analysis. The results offer little support for Hypothesis 1, as there was no significant relation between size (measured as employees or, alternatively, as annual sales) or performance (market/book) on firms' propensity to join the GBC. In contrast, we find a significant positive relation between foreign sales and GBC membership, consistent with Hypothesis 2. On average, GBC member firms derived 37 percent of their sales from outside the US, compared with an average of less than 20 percent for non-members. Pharmaceutical companies were far more likely to join the GBC than other firms, consistent with Hypothesis 3: the coefficient implies that pharmaceutical companies are 6.7 times as likely to be members of the GBC as firms in other industries. As predicted by Hypothesis 4, firms with domestic partner benefits were almost five times as likely to be members of the GBC as firms without such policies. Interestingly, similar effects were also observed when we used a more diffuse measure of 'diversity-friendliness' in HR policies, using the KLD Database's Diversity Strengths measure instead of HRC's WorkNet data on companies with domestic

Table 14.1 Descriptive statistics and correlation matrix for Fortune $\mathbf{5 0 0}$ firms

\begin{tabular}{lrrrrrrr}
\hline Variable & Mean & 1 & 2 & 3 & 4 & 5 & 6 \\
\hline 1. GBC membership & 0.05 & & & & & & \\
2. Employees & 17.37 & -0.01 & & & & & \\
3. Market-to-book value & 2.84 & 0.15 & -0.03 & & & & \\
4. Foreign sales \% & 19.92 & 0.18 & 0.02 & 0.19 & & & \\
5. Board interlock with existing GBC member & 0.68 & 0.28 & 0.02 & 0.11 & 0.12 & & \\
6. Pharmaceutical company & 0.02 & 0.28 & -0.01 & 0.21 & 0.12 & 0.09 & \\
7. Domestic partner health benefits & 0.45 & 0.20 & -0.04 & 0.09 & 0.06 & 0.25 & 0.16 \\
\hline
\end{tabular}


Table 14.2 Logistic regression: factors distinguishing Fortune $\mathbf{5 0 0}$ firms that joined the global business coalition on HIVIAIDS

\begin{tabular}{llr}
\hline Variable & Coeff. & \multicolumn{1}{c}{$\mathrm{z}$} \\
\hline Employees & 0.00 & -0.02 \\
Market-to-book value & 0.04 & 0.47 \\
Foreign sales \% & $0.04^{*}$ & 2.81 \\
Board interlock with existing & & \\
$\quad$ GBC member & $0.50^{*}$ & 3.66 \\
Pharmaceutical company & $1.91^{*}$ & 2.20 \\
Domestic partner health benefits & $1.58^{*}$ & 2.36 \\
Constant & -5.92 & -7.28 \\
\hline${ }^{*} p<.05$ (two-tailed) & &
\end{tabular}

partner benefits. And lastly, we found that ties to other firms that were GBC members had a strong effect. Specifically, each board interlock with a GBC member increased a firm's likelihood of being a member by 64 percent.

Two of our findings stood out as somewhat surprising from the perspective of the traditional literature on corporate social responsibility (e.g., Margolis and Walsh, 2001). First, firms with progressive HR policies on diversity, both generally and specific to gay and lesbian employees, were significantly more likely to be involved in the GBC. There are at least two possible interpretations of this finding: such firms may have a culture more attuned to issues of social responsibility, and thus find activism around the AIDS epidemic to be a natural response, or they may have internal constituencies that argue in favor of external responsiveness. Edelman (1992) and Kelly and Dobbin (1999) find that firms creating HR offices in response to the Civil Rights Acts of the mid-1960s - sometimes as a cynical effort to ward off potential litigation - end up building internal constituencies for progressive HR policies, and later find themselves being in the forefront of adopting policies such as paid maternity leave. By the same token, it is possible that firms with progressive diversity policies developed internal constituencies attuned to the AIDS epidemic. Indeed, an interview we conducted with the officer in charge of one multinational firm's award-winning AIDS program in Africa revealed that the program originated in one
US-based mid-level manager's championing of the program.

Second, we found a strong and consistent relation between being a member of the GBC and board-level ties to other GBC members. Figure 14.1 shows this graphically (including ties to non-US firms traded on Nasdaq and NYSE that are GBC members). Our finding parallels McAdam's (1986) study of Freedom Summer: while moral commitments may shape responsiveness to calls for activism, social connections to other activists may have a more direct effect. We also note a somewhat surprising connection: every Fortune 500 firm with an African-American CEO (American Express, Fannie Mae, Merrill Lynch, and Time Warner) was a member of the GBC in 2004, as were almost all the firms whose board these CEOs served on. (Fannie Mae's Franklin Raines served on the boards of Pepsico, Pfizer, and Time Warner; Time Warner's Richard Parsons served on the boards of Citigroup and Estee Lauder; in contrast, GM, whose board Merill Lynch's Stanley O'Neal served on, was not a member, nor was IBM, where AmEx's Kenneth Chenault served). Moreover, GM subsequently joined the GBC, while Fannie Mae left the GBC after the departure of its African-American CEO. This intriguing observation suggests a source of social responsiveness unexpected in the traditional literature.

\section{DISCUSSION}

We framed our discussion of American corporations joining the global fight against HIV/AIDS as an instance of failed institutionalization. Speaking to an audience of America's top business leaders, UNAIDS Executive Director Peter Piot (2004) declared, '[You] have a special role. [You] are the only [ones] whose leadership can move the world - not just with funding - but with the influence it takes to keep AIDS high on the international agenda.' He then posed 


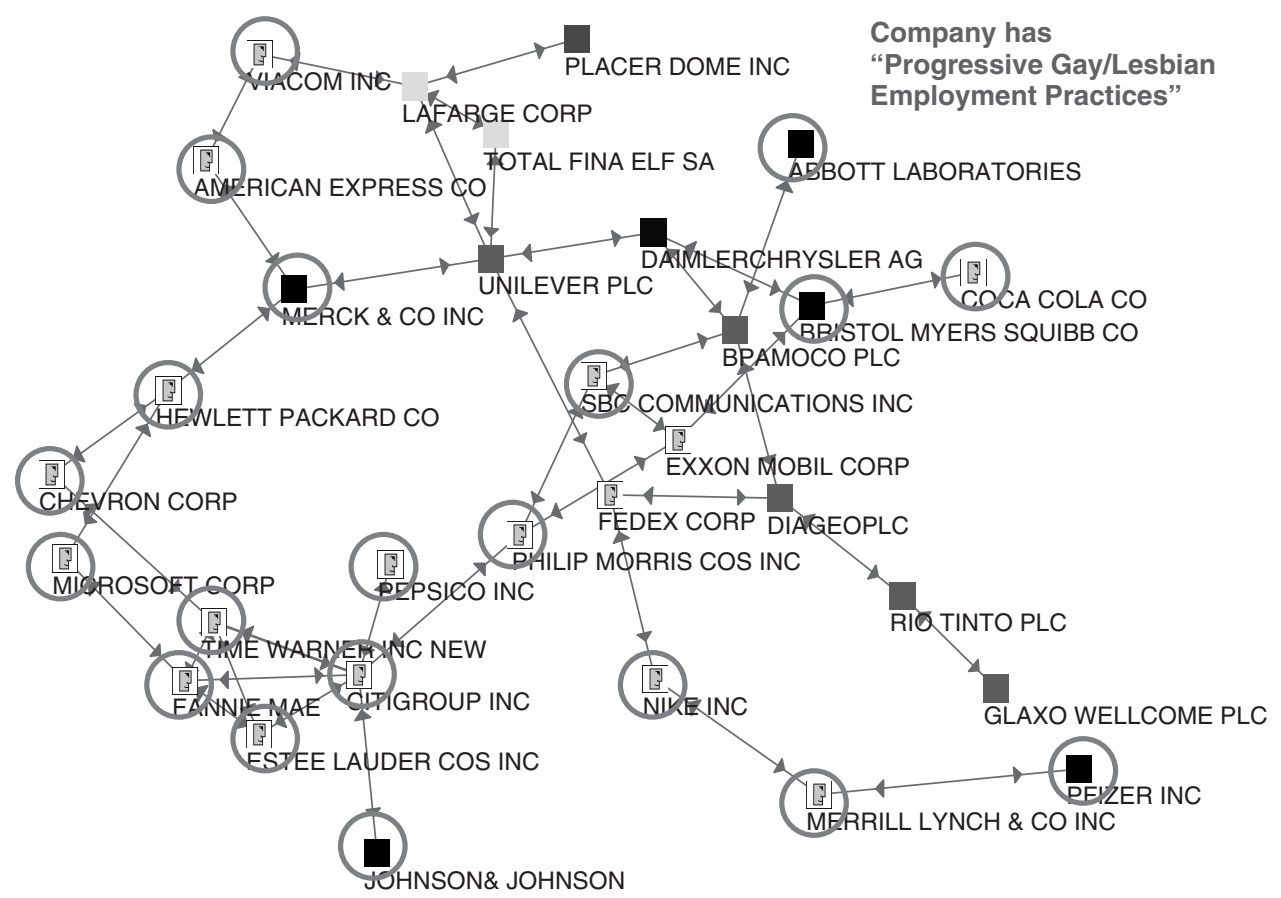

Figure 14.1 Board ties among GBC members

to them the question that forms the foundation of this research effort, 'We are clearly at a crossroads in the global fight, which path will [you] take?' (Piot, 2004: 7-8). Piot's comments underscore the critical question that US business leaders find themselves facing: is it worth the investment of their companies to engage in the global fight against HIV/AIDS? (Nattrass, Neilson, Bery, Mistry, and Sievers, 2004). In the event, the large majority answered: No.

Our results indicate what factors distinguished the handful of firms that did join the GBC from those that did not. Membership in the Global Business Coalition on HIV/AIDS serves as a valuable measure of action, as the GBC has emerged over the past few years as the world's most influential business coalition addressing the epidemic, offering member corporations a wide range of ways to become involved and connecting them to many, if not all, of the leading corporate and public sector actors active in the fight against HIV/AIDS. Moreover, membership was cheap, and thus set a relatively low threshold for 'corporate activism.' Yet the results suggest that incentives were not the deciding factor: bigger firms, and those with better performance, were no more prone to join the GBC than small firms with poor performance. Evidently the cost of membership was not a significant hurdle for firms of this size. Pharmaceutical firms were far more likely than others to join, but this result is potentially ambiguous. Pharmaceutical firms have economic incentives to claim a place at the table when it comes to AIDS policies, and they also have reasons to signal their good faith to outside evaluators by joining in efforts to combat the disease (cf. Meyer and Rowan, 1977). But they have less cynical reasons to join as well, based on their identity as health providers. With only archival data, it is impossible for us to disentangle these alternative interpretations. 
Similarly, firms with greater foreign sales were more prone to join the GBC than domestically-oriented companies. Again, this may be because such firms had greater selective incentives to join (because membership gave them access to tools for constructing their own policies for overseas facilities), or because such firms were more aware from first-hand experience of the impact of the epidemic.

More intriguing are our results on network factors associated with membership. Research on social movements and on organizational institutionalism both highlight the central place of social networks in processes of change. Organizations look to their peers and competitors to determine what is appropriate in a given context, and to answer the question 'What does someone like me do in this situation?' (DiMaggio and Powell, 1991). Social movement participants can act as evangelists, recruiting their friends and colleagues to participation. In this case, Kofi Annan and others were seeking to build a social movement among corporations, to change the definition of what a corporation's obligations are with respect to the global fight against the AIDS epidemic.

We examined two types of networks that might serve as a basis for legitimation and recruitment to the GBC. First, organizations that have adopted domestic partner benefits often share a connection through employee activist networks. About 45 percent of the large US corporations in our sample offered such benefits, and prior work suggests that such firms are connected by informal interorganizational networks of employees; indeed, such networks were in part the basis of advocacy for these benefits (Briscoe and Safford, 2005; Scully and Creed, 2005). But while firms with such benefits were more likely to join the GBC than those without, we saw little evidence of contagion, as only a relatively tiny proportion of firms with domestic partner benefits joined the GBC. This suggests that the inter-organizational network facilitating human resource policies was not activated for recruitment to the GBC. Rather, the findings indicate that firm-level features made organizations with partner benefits more receptive to the call to join. By virtue of taking a progressive step regarding gay-friendly HR policies, a firm is likely to attract employees who are generally more attentive to certain social causes, specifically AIDS-related issues, who might then act as internal advocates for the GBC.

In contrast, we find that network ties through boards of directors were a relatively potent source of recruitment - with some qualifications. This parallels the board-based contagion process of other practices and structures that came to be widespread (e.g., the poison pill and the creation of investor relations offices, both of which came to be standard practice among corporations). But in this case, adoption stalled at only about 5 percent, as GBC membership failed to become institutionalized. An unexpected finding may help explain this. We discovered that every Fortune 500 firm with an AfricanAmerican CEO (of which there were four at the time of our analysis, now down to threes was a member of the GBC, and almost every board that these CEOs served on was a member of the GBC. It seems clear that the actions of some firms - such as Fannie Mae, whose business consists primarily in securitizing American home mortgages - did not result from a direct pecuniary interest in stemming the AIDS pandemic, particularly given that they do essentially no business in the hardest-hit nations. Rather, their responsiveness to the call to action evidently resulted from other motivations. This is not trivial: four black CEOs collectively served on the boards of over one-third of the GBC's American members, and almost half the GBC's US members shared directors with the firms these four ran.

This finding indicates an alternative framing of the question that we began with. Rather than asking: 'Why did US corporations join the global fight against AIDS?', we might instead ask 'Why did most US corporations fail to join the fight?' The early adopters were largely distinguished by a small number of factors: either they had 
direct business interests in the fight against AIDS (pharmaceutical companies, multinationals doing substantial business in Africa) or they had board ties to the four large firms run by African-American CEOs at the time (American Express, Fannie Mae, Merrill Lynch, Time Warner). Although speculative, this suggests that recruitment based on networks (rather than incentives) spread only as far as the reach of these four firms. Had the directors of these first-degree contacts acted as evangelists, recruiting the other firms whose boards they served on in turn, it is possible that GBC membership would have reached a critical mass of prevalence sufficient to legitimate it as part of the standard package of what US corporations do. In short, it would have become institutionalized, an appropriate response to corporate America's collective corporate social responsibility toward world health. Instead, we found that most corporations abstained, either due to inertia, a lack of incentives, or the (accurate) perception that most of the damage would be felt on someone else's watch.

We recognize that there are limitations in our approach that prevented us from capturing a company's full involvement in the fight against HIV/AIDS. For data analysis convenience, we used a gross dependent variable, namely 'GBC member' or 'not a GBC member' to assess Fortune 500 firms' involvement. Ideally, we would like to know more about the specific details of each Fortune 500 firms' HIV/AIDS programs and policies. Cursory analysis of the GBC members' respective HIV/AIDS programs seems to indicate quite a variance in regards to how different companies are engaged in fighting the global epidemic. One potential way to analyze the differences in GBC members' HIV/AIDS programs would be to conduct research along the lines of Westphal, Gulati and Shortell's (1997) analysis of firms' adoption of TQM practices. Their work demonstrated that early and later adopters of TQM differed in how they employed TQM practices within their companies. It might be equally interesting to examine whether there is a substantive difference in the HIV/AIDS programs of those Fortune 500 firms who joined the GBC early, as compared to those who joined later. The primary impediment in conducting such an analysis at this point is that there is little uniformity in the way that companies report their HIV/AIDS programs. Future research would do well to explore this in more detail.

\section{CONCLUSION}

We argued at the outset that organizational institutionalism and social movement theory offered complementary insights into explaining failed institutionalization. Organizational insititutionalists seek to understand how practices and structures come to be accepted and even taken for granted: why do all large American corporations have someone with a title 'Chief Executive Officer;' almost all have investor relations offices and Chief Financial Officers; and a large majority have poison pills and golden parachutes? This question can be extended to issues of social responsibility: why do so many companies headquartered in Minneapolis support local non-profit arts organizations, while those in Columbus, Ohio support child welfare, and those in Orange County, California provide little support to any non-profits (Marquis et al., 2007)? The answer turns on field-level processes of definition and re-definition, where the prevalence of a practice serves as an indicator of legitimacy and a spur to further adoption. Successful institutionalization projects are those in which a practice becomes sufficiently widespread that it becomes acceptable and even obvious. Social movement theory focuses on similar dynamics to explain the prevalence of activism and social change. In the corporate sector, for instance, activists sought to make domestic partner benefits for GLBT employees acceptable and even obligatory. 
No such process occurred for responses to the AIDS epidemic. Given a low-cost opportunity to engage in collective action aimed at addressing the worst public health crisis in recent history through the GBC, the vast majority of American corporations took a pass. Perhaps their incentives were too weak - yet most surveyed executives themselves regard their own corporate policies as inadequate to address HIV/ AIDS. Moreover, many of the firms that did join the effort did little or no business in sub-Saharan Africa, where the greatest need is felt. Pharmaceutical and oil companies have clear incentives to join the conversation based on their business interests, but why mortgage companies and financial services firms?

Our results indicate that collective action failed to reach critical mass and thus to achieve a taken-for-granted status. Some corporations joined because of their immediate economic interest. Others evidently joined because they employed individuals with a rooting interest in the cause, or were recruited through ties to such activists. But in the end, the numbers were not sufficient to reach a tipping point in which joining the coalition was the sanctioned means of addressing the HIV/AIDS crisis. Prior research on corporate change indicates that practices that were initially highly controversial can come to be legitimated and widespread through the observed prevalence of the practice (e.g., Davis and Greve, 1997). Ironically, our examination suggests that failure to achieve some level of prevalence can undermine the spread of practices that should be utterly uncontroversial, and even mandatory.

\section{ACKNOWLEDGMENT}

We would like to thank the Center for Advancing Research and Solutions for Society (CARSS) at the University of Michigan for their support of this project.

\section{REFERENCES}

Annan, K. 2001. Unparalleled nightmare of AIDS. Address to the United States Chamber of Commerce. Washington, D.C. 〈www.un.org/News/Press/docs/2001/sgsm78 27.doc.htm〉.

Bazerman, M. \& Watkins, M. 2004. Predictable Surprises: The disasters you should have seen coming and how to prevent them. Cambridge, MA: Harvard Business School Publishing.

Briscoe, F. \& Safford, S. 200,5. Agency in diffusion: Activism, imitation and the adoption of domestic partner benefits among the Fortune 500. Working paper, University of Chicagg

Cyert, R.M. \& March, J.G. 1963. A behavioral theory of the firm. Cambridge, MA: Blackwell Publishers.

Davis, G. F., and Greve, H. R. 1997. Corporate elite networks and governance changes in the 1980s. American Journal of Sociology, 103: 1-37.

Davis, G. F. and McAdam, D. 2000. Corporations, celasses, and social movements after managerialism. In Barry Staw and Robert I. Sutton (eds.), Research in organizational behavior, 22: 193-236. Oxford, UK: Elsevier Science.

Davis, G. F., McAdam, D., Scott, W. R., and Zald, M. N. (eds.). 2005. Social movements and organization theory. New York: Cambridge University Press.

Davis, G. F., Whitman, M. vN., and Zald, M. N. 2007. The responsibility paradox: Multinational firms and global corporate social responsibility. Unpublished, University of Michigan.

Davis, G. F., and Zald, M. N. 2005. Social change, social theory, and the convergence of movements and organizations. In G. F. Davis, D. McAdam, W. R. Scott, and M. N. Zald. Eds), Social movements and organization theory, 335-350. New York: Cambridge University Press.

DiMaggio, P. J. and Powell, W. W. 1983. The iron cage revisited: Institutional isomorphism and collective rationality in organizational fields. American Sociological Review, 48: 147-160.

DiMaggio, P. J., and Powell, W. W. 1991. Introduction to the new institutionalism. 
In Walter W. Powell and Paul DiMaggio (eds.), The new institutionalism in organizational analysis, 1-38. Chicago: University of Chicago Press.

Dobbin, F., Sutton, J. R., Meyer, J. W., and Scott, W. R. 1993. Equal opportunity law and the construction of internal labor markets. American Journal of Sociology, 99: 396-427.

Eberstadt, N. 2002. The future of AIDS. Foreign Affairs, 81: November/December 2002.

Edelman, L.B. 1992. Legal ambiguity and symbolic structures: Organizational mediation of civil rights law. American Journal of Sociology, 97: 1531-1576.

Fligstein, N. 1990. The transformation of corporate control. Cambridge, MA: Harvard University Press.

Global Business Coalition on HIV/AIDS. 2004. 〈www.businessfightsaids.org/site/pp.asp?c=n mKOLaP6E\&b=202240 . Accessed December 28, 2004.

Greenwood, R. and Suddaby, R. 2006. Institutional entrepreneurship in mature fields: The Big Five accounting firms. Academy of Management Journal, 49 (1): 27-48.

Hedstrom, P. and Swedberg, R. 1998. Social mechanisms: An analytic approach to social theory. New York: Cambridge University Press

Human Rights Campaign. 2004. WorkNet. Washington, DC. Human Rights Campaign Foundation. 〈www.hrc.org/Template.cfm? Section=About_HRC_WorkNet $\rangle$.

Kelly, E. and Dobbin, F. 1999. Civil rights law at work: Sex discrimination and the rise of maternity leave policies. American Journal of Sociology, 105: 455-492.

Margolis, J. and Walsh, J. 2001. People and profits? The search for a link between a company's social \& financial performance. Mahwah, NJ: Lawrence Erlbaum and Associates.

Marquis, C., Glynn, M. A., and Davis, G. F. 2007. Community isomorphism and corporate social action. Academy of Management Review 32:925-945.

Marquis, C. 2003. The pressure of the past: Network imprinting in intercorporate communities. Administrative Science Quarterly, 48: 655-689.

McAdam, D. 1986. Recruitment to high-risk activism: The case of Freedom Summer. American Journal of Sociology, 92: 64-90.
Meyer, J. W. and Rowan, B. 1977. Institutionalized organizations: Formal structure as myth and ceremony. American Journal of Sociology, 83:41-62.

Nattrass, N., Neilson, T., Bery, P., Mistry, N. and Sievers, S.E. 2004. Opportunities for business in the fight against HIVIAIDS. Discussion paper initiated by Columbia University, The Global Business Coalition on HIVIAIDS and the University of Capetown.

Palmer, D. A., Jennings, P. D., and Zhou, X. 1993. Late adoption of the multidivisional form by large U.S. corporations: Institutional, political, and economic accounts. Administrative Science Quarterly, 38:100-131.

Pfeffer, J. and Salancik, G.R. 1978. The external control of organizations. Stanford, California: Stanford University Press.

Piot, P. 2004. AIDS and the way forward: A World AIDS Day Address. Address to the Woodrow Wilson International Center for Scholars. Washington, DC 〈www.unaids. org/html/pub/media/speeches02/sp_piot_wil soncenter_30nov04_en_pdf.htm $\rangle$. Accessed January 5, 2005.

Rao, H. 2002. Tests tell: Constitutive legitimacy and consumer acceptance in the American automobile industry, 1985-1912. In Paul Ingram and Brian Silverman (eds.), The new institutionalism in strategic management, 307-339. JAl Press.

Rao, H., Davis, G. F., and Ward, A. 2000. Embeddedness, social identity and mobility: Why firms leave the NASDAQ and join the New York stock exchange. Administrative Science Quarterly, 45: 268-292.

Scully, M. A. and Creed, W. E. D. 2005. Subverting our stories of subversion. In G. F. Davis, D. McAdam, W. R. Scott, and M. N. Zald (eds.), Social movements and organization theory, 310-332. New York: Cambridge University Press.

Strang, D. and Soule, S. A. 1998. Diffusion in organizations and social movements: From hybrid corn to poison pills. Annual Review of Sociology, 24: 265-290.

Sutton, J.R. and Dobbin, F. 1996. The two faces of governance: Responses to legal uncertainty in U.S. firms, 1955 to 1985. American Sociological Review, 61: 794-811. 
Sutton, J.R., Dobbin, F., Meyer, J.W. and Scott, W.R. 1994. The legalization of the workplace. American Journal of Sociology, 99: 944-971.

Taylor, K., DeYoung, P., \& Boldrini, F. 2004. Business and HIV/AIDS: A Global Snapshot. Geneva: World Economic Forum.

Thailand Business Council on AIDS (TBCA). 2000. The business response to AIDS in Thailand. 〈Http://abconaids.org/ABC/asp/ DispDoc.asp?DocID=294〉. Accessed January 6. 2005.

Tilly, C. 1978. From mobilization to revolution. New York: Random House.

Walsh, J. 2005. Taking stock of stakeholder management. Academy of Management Review, 30:420-438.
Westphal, J.D., Gulati, R., and Shortell, S.M. 1997. Customization or conformity? An institutional and network perspective on the content and consequences of TQM adoption. Administrative Science Quarterly, 42: 366-395.

World Economic Forum. 2004. Business and HIVIAIDS: Who me? Geneva, Switzerland: World Economic Forum Global Health Initiative.

Zald, M. N., Morrill, C., and Rao, H. 2005. The impact of social movements on organizations: Environment and responses. In G. F. Davis, D. McAdam, W. R. Scott, and M. N. Zald (eds.), Social Movements and Organization Theory, 253-279. New York: Cambridge University Press. 